\title{
Study Food Habits of Fishes in Tempe Lake
}

\section{Muh.Hatta $^{1}$, Nur Asia Umar ${ }^{2}$, Sri Mulyani ${ }^{3}$, Ida Suryani ${ }^{4}$}

\author{
${ }^{1}$ Faculty of Marine Scienes and Fisherie Hasanuddin University, Indonesia \\ hattaik19@yahoo.com \\ ${ }^{2}$ Faculty of Fisheries Cokroaminoto University of Makassar, Indonesia \\ nurasia0005@yahoo.com \\ ${ }^{3}$ Faculty of Fisheries Bosowa University, Indonesia \\ smjournal45@gmail.com \\ ${ }^{4}$ Faculty of Agricultural Technology Cokroaminoto University of Makassar, Indonesia \\ idastantu@gmail.com
}

\begin{abstract}
This study aims to analyze and classify the food habits offish with economic value in the waters of Lake Tempe in several different types of fish.

The research was conducted in February, March, April, and June 2017 at Tempe lake in South Sulawesi. The research method used is the method of field observation and observation in laboratory. Several samples offish species observed were 25 Snakeheadfish (Channa striatus), 30 Goldfish (Cyprinus carprio), 40 Snakeskin fish (Trichogaster pectoralis), 40 Javabarb fish (Barbonymus gonionotus), 40 As many as 40 Tilapia (Oreochromis niloticus), and 40 Damselfish (Anabas testudineus). The types of organisms found in the fish's gastric are then identified by using the 1979 Yamaji plankton identification book, and then calculating the frequency of occurrence to classify the food habits offish.
\end{abstract}

The results showed that Snakeskin fish and tilapia fish were classified as herbivore fish based on gastric contents analysis found in phytoplankton, zooplankton, detritus, aquatic plants, insects, other benthic invertebrates and worms. Goldfish and Damselfish are classified as omnivoro fish based on gastric contents analysis obtained by water plants, phytoplankton, zooplankton, zoobentos, detritus, insects, molluscs, worms, eggs or fish larvae and other invertebrate larvae. While Javabarb fish are classified as planktivor fish based on gastric contents analysis found phytoplankton, zooplankton, aquatic plants, insects, and other invertebrate larvae. Fish Snakehead fish classified as carnivore fish based on gastric contents analysis found zoobenthos, fish, shrimp, crustaceans, worms, frogs, and nekton. Based on the measurement of water quality parameters shows that the carrying capacity of the environment as a habitat is still very supportive for the growth offish in the waters of Tempe lake.

Keyword-Food Habits, Snakehead fish, Goldfish, Snakeskin fish, Javabarb fish, Tilapia, Damselfish, Tempe lake.

\section{INTRODUCTION}

Tempe lake is one of the largest lakes in Indonesia located between 3 districts of Wajo, Soppeng and Sidrap regencies. The area of Tempe lake between 13.000 - 15.000 hectares, has an important role in the economy People living around the lake.

Tempe lake has a wealth of abundant freshwater fish, presumably because the island of Sulawesi including the Wallacea region which is a transition between Oriental and Australian zoogeography (Whitten et al., 1987), there are many species of endemic flora and fauna, including fish. Some studies suggest that extreme geographic differences may affect the existing fish community structure in these waters (Carmona et al. 1999 and Pyron and Lauer 2004).
Indonesia is the second highest country of freshwater diversity after Brazil of 1300 species and Tempe lake is the largest supplier of freshwater fish consumption in Indonesia (Tamzil, 2000). The waters that have many sources of fish food, Tempe lake become an ideal ecosystem for breeding freshwater fish. In addition to freshwater fish for consumption, Tempe Lake is also rich in freshwater ornamental fish. From the process of forming the lake, making Tempe lake has several species of endemic freshwater fish. Several types of endemic fish is also a commodity export even to the European and American kebenua. For example Celebes Rainbow fish (Marosatherinaladigesi) and Binishi fish (Oryzias celebensis) (Effendie, 2007).

Some species of fish found around Tempe lake are snakehead fish (Channa striata), damselfish (Anabas 
Testudineus), snakeskin (Trichogaster pectoralis), catfish (Clarias batrachus), goldfish (Cyprinus carpio), javabarb fish (Puntius javanicus), nilem (Osteochilush asselti), mujair (Oreochromis mossambica), tilapia (O. niloticus), beloso fish (Glossogobius giuris), Eel (Anguilllamar morata), Swamp eel (Monopterus albus) and Mullet (Mugil cepha), and Sapu-sapu fish (Liposarcus pardalis) (Samuel, et al. 2010). These fish species are fish that many consumed by society and some have been cultivated.

Based on interviews from the Fisheries and Maritime Affairs staff of Soppeng and Wajo districts as well as interviews from fishermen communities around Tempe Lake that Tempe Lake is silting due to the many weeds or water hyacinths that grow where both of these plants roots to the bottom so that this roots as a war, waste vessels, and others carried by rivers connected to the lake (Unru, 2010). Such conditions can lead to reduced fish diversity.

Therefore, our research aimed to find out the favorite natural foods of some dominant fish caught and whether the fish belong to herbivorous, omnivorous or carnivore fish species, so with this research it is easier for the fishermen community if they want to cultivate the fish on ponds or ponds. It is also hoped that with this study we can find out whether the carrying capacity of the environment as a habitat is still high enough to support the growth of the fish in Tempe lake as stated by Khoiriya (1999) in Widyorini, N. (2009) that the growth of a population or individual is closely related to the existence of food in their area of life.

\section{RESEARCH METHODS}

The research was conducted in Tempe lake of Soppeng Regency for 4 months (February, March, April, and June) in 2017. The method used in this research is the field observation and observation in the laboratory.

Fish sampling is done in a complete random manner called Complete randomized Sampling (Zar, 1984). It is a sampling technique by providing equal opportunity for each member of the population to be a research sample. Determination of fish species that analyzed the contents of the gastric is based on the dominance and economic value of the fish species caught during the study. There are several species of fish caught but the dominant are Snakeskin fish (Trichogaster pectoralis), goldfish (Cyparinus carpio), Javabarb fish (Barbonymus gonionotus), Tilapia (Oreochromis niloticus), Damselfish (Anabas testudineus) and Snakehead fish (Channa striatus). The number of fish samples analyzed the contents of the stomach each month are 25 fish Snakehead fish, 30 goldfish and 40 Snakeskin, Javabarb,Tilapia and Damselfish.

Sampling of the dominant fish is the first measured the length and weight of the body, then dissected and removed the intestines or intestine fish intact. The gastric weight of fish that has been dissected and then weighed and preserved with a solution of 4 $10 \%$ formalin solution in the sample bag is further identified and analyzed in the laboratory (Hatta, 2010).

Identification of food type in fish intestines aims to know fish food habits (Effendie, 1979) by observing the contents of fish digestive organs, observations performed under a microscope. Identification of food type was done by using plankton identification book from Yamaji, (1979). The types of organisms found in fish hulls were then identified and calculated the frequency of occurrence for the classification of feeding habits (planktivore / herbivore, omnivore and carnivore) Paulyat.all (2000).

Physical and chemical parameter data of waters is measured as supporting data. Measurements were taken in conjunction with fishing. Physical and chemical parameters measured include temperature, salinity, current velocity, depth and brightness.

\subsection{Food Habits}

\section{RESULT AND DISCUSTION}

The results of observations of gastric contents of the six dominant fish species found in Tempe Lake and the classification based on the main food are presented in Table 1.

Table.1: Types offood and classification based on main food 6 dominant fish species found in Tempe Lake

\begin{tabular}{|c|l|l|c|}
\hline Types of fish & $\begin{array}{l}\text { Length and weight } \\
\text { of fish }\end{array}$ & \multicolumn{1}{|c|}{ Types of food } & $\begin{array}{c}\text { Classification } \\
\text { by main food }\end{array}$ \\
\hline Snakeskin fish & $\begin{array}{l}\mathrm{P}: 11,5-17,1 \mathrm{~cm} \\
\mathrm{~W}: 21,3-40,8 \mathrm{gr}\end{array}$ & $\begin{array}{l}\text { phytoplankton, zooplankton, detritus, aquatic plants, } \\
\text { insects and other benthic invertebrates }\end{array}$ & Herbivore \\
\hline Goldfish & $\begin{array}{l}\mathrm{P}: 20 \mathrm{~cm}-25 \mathrm{~cm} \\
\mathrm{~W}: 200-300 \mathrm{gr}\end{array}$ & $\begin{array}{l}\text { water plants, zooplankton, zoobenthos, crustaceans, } \\
\text { insecta, worms, eggs or fish larvae and detritus }\end{array}$ & Omnivore \\
\hline Javabarb fish & $\begin{array}{l}\mathrm{P}: 16,2-19,2 \mathrm{~cm} \\
\mathrm{~W}: 62,0-97,8 \mathrm{gr}\end{array}$ & $\begin{array}{l}\text { phytoplankton, zooplankton, aquatic plants, insects, and } \\
\text { other invertebrate planktons }\end{array}$ & Planktivore \\
\hline
\end{tabular}




\begin{tabular}{|c|l|l|c|}
\hline Tilapia fish & $\begin{array}{l}\mathrm{P}: 9,5-29 \mathrm{~cm} \\
\mathrm{~W}: 50 \mathrm{gr}-500 \mathrm{gr}\end{array}$ & $\begin{array}{l}\text { Water plants, phytoplankton, zooplankton, zoobenthos, } \\
\text { detritus, insects and worms }\end{array}$ & Herbivore \\
\hline Damsel fish & $\begin{array}{l}\mathrm{P}: 10 \mathrm{~cm}-14,5 \mathrm{~cm} \\
\mathrm{~W}: 10 \mathrm{gr}-70 \mathrm{gr}\end{array}$ & $\begin{array}{l}\text { Water plants, phytoplankton, zooplankton, zoobenthos, } \\
\text { detritus, insects, molluscs, worms, eggs or larvae of fish } \\
\text { and other invertebrate larvae }\end{array}$ & Omnivore \\
\hline Snakehead fish & $\begin{array}{l}\mathrm{P}: 15-39 \mathrm{~cm} \\
\mathrm{~W}: 40-710 \mathrm{gr}\end{array}$ & $\begin{array}{l}\text { zoobenthos, fish, shrimp, other crustaceans, worms, frogs } \\
\text { and other nekton }\end{array}$ & Carnivore \\
\hline
\end{tabular}

The result of gastric contents analysis showed that Snakesin fish and tilapia fish is dominant to be classified as herbivore fish because in the gut obtained a high proportion of water plants with high emergence frequency. Both types of fish also consume plankton and detritus. Javabarb dominant to be planktivorous with the proportion and appearance of plankton high enough in the intestine. The same thing has been observed by Samuel et al (2010) in Tempe Lake that states that Snakeskin fish, tilapia and javabarb are plankton eater especially phytoplankton, although in the third intestine the fish are found some insecta animal organism does not mean the fish are eater of the organism but the likelihood of insecta is prevalent in these waters, as Effendie (1979) says, that the spread of the most types of food will cause the uptake of the species to increase.

From the table one it is also seen that the goldfish eat in the form of plankton, aquatic plants, insects, worms and eggs or other fish larvae, so the goldfish was classified as omnivore fish. Pudjirahayu.dkk (2008) stated that goldfish usually dig the basic substrate in the turbid waters to get the food but the goldfish are also able to utilize the stems, leaves and seeds of both water and ground plants. Damselfish classified as omnivorefish that tend to be carnivore because in the gut found a type of eating that is very varied as goldfish but found also some types of molluscs and other invertebrate larvae. Snakehead fish is supposed to be carnivore fish because in the contents of its stomach many found some other fish such as snakeskin fish, damselfish, tilapia and other types of fish smaller size, besides snakehead fish also preyed some other animal like frog and very often got intestine full with one or more fish.

Based on the observation time it is seen that herbivore fish such as snakeskin fish and tilapia have the composition of the fraction per item of gastric contents related to rainfall. In the rainy season where the volume of Tempe water increases so that the water boundary extends towards the land hence the contents of the hull of both types of fish this has a percentage of aquatic plants such as parts of grass and leaves are quite high. This is because in such conditions the fish tend to migrate to the boundary of water that contains many foods in the form of water plants that border on land, as stated by Binder T.R. at.all, (2011), that one of the causes of migration from fish is due to food. This is evident from the increased catch of fishermen who install nets or trawlers in shallow waters on the coast when the water rises. Usually fishermen install fishing gear in areas that have vegetation such as rice fields and vegetated coastal areas.

Unlike snakeskin fish and tilapia fish, javabarbfish that prey on plankton dominant to inhabit clearer waters and prefer to be on the surface so that despite migration when the water rises but not too to the edge like fish snakeskin fish and tilapia. This causes the variation of intestinal contents of tawes fish more influenced by the abundance of plankton in water. Goldfish that are close relatives to javabarb have a larger food spectrum compared to javabarb fish. Goldfish have the ability to consume water plants are relatively larger and other food items in the form of worms and insects show that goldfish has a relatively larger choice of food when compared with javabarb fish. However, goldfish does not show significant differences between observations that indicate that although the availability of one type of food overflows in a certain time but the goldfish still consume other types of food items so that the variation of the content of the gastric is not too different from time to time.

Damselfish is a fish that categorized all the food with the most diverse food items when compared with other types of fish. They are able to consume almost all types of food ranging from plankton, aquatic plants, detritus, insects, molluscs, eggs / larvae of fish and various other types of invertebrate larvae. Its ability to adapt to a variety of habitats and utilize various types of food causes this type of fish is almost obtained in all water conditions. The fish is able to adapt to extreme environments such as in mud and water shortages. The tendency to prey on different types of fish and other invertebrate larvae appears to be consistent with the increasing size of fish. Worms as fish food damselfish utilized by the fisherman anglers as bait, especially earthworms the size is rather smooth 
Snakehead fishis a predatory fish that preys on various types of fish, shrimp and various other nekton species including amphibious animals such as frogs and other reptiles. Observation of the contents of the stomach shows that very often found snakehead fish hull filled with one or several species of fish such as snakeskin fish, tilapia, damselfish and frog are still intact and very easy to identify. In other conditions found the contents of snakehead fishgastric consists of fish or shrimp that is not clear the type but still can be distinguished of parts such as head and tail but has crushed the scales and fins. In empty intestine conditions the snakehead fish usually only consists of a rather coarse material such as sand mixed with other parts of the fish but has been destroyed.

As a carnivore, snakehead fish adjusts the size of its food by exchange opening its mouth. Smaller snakeheadfish usually found in the gastric fish or shrimp are smaller, the size of the food also increases with the increase in the size of fish. As a carnivor fish use oral organs that have a wide enough openings and equipped with strong enough teeth (War at.all, 2011). Intestine orgastric is very thick though short so as to enlarge and shrink according to the size of the food. When viewed from the frequency of presence of fish species that are often found in snakehead fishhulls it appears that fish javabarb fish and goldfish relatively more rarely found when compared with snakeskin fish, tilapia and damselfish. This is caused by the habit of snakehead fish that inhabit the bottom of the waters with a little vegetation has the likeness of the favorite habitat of snakeskin fish, tilapia and damselfish. Thus the intersection between snakehead fish with these three types of fish is relatively larger and facilitate the occurrence of predation.

Changes in the type of fish food damselfish as omnivor fish that tend to carnivore and snakehead fish as carnivore fish showed the variation between time observations. This change is related to changes in the type of food that is influenced by environmental factors. This is particularly evident when the lake's surface water conditions rise (rainy season) occurring in June where the food items of the fish species declined somewhat compared to the previous month where the volume of Lake Tempe water was smaller. These food item changes are related to the behavior of prey fish who migrate and tend to the edge to look for food such as snakeskin fish and tilapia. This reduces the chances of predation because corks that tend to survive in a particular territory do not follow the movement of their prey so quickly that their food items from other groups such as worms, insects and other vertebrates increase. The damselfish of the moon also migrate to the waterfront to feed on water plants and larger ones and have mature gonads utilize these conditions for spawning. This migration also affects the fish food item of the fish in the month.

Referring to the results of the gastric contents analysis when it is associated with habitat and response to environmental changes, there is a link between habitat preference and the eating habits of the six fish species studied. Further linkage is related to the existence and survival of each species in the ecosystem in Tempe lake. The snakeskin fish as herbivore with main food of natural aquatic plants usually spawn early in the rainy season so that juvenile fish have adequate availability of food at the height of rising water and the opportunity to the edge of the lake to eat various types of vegetation is quite abundant. This leads to the peak of the rainy season where the maximum water content of the snakeskin fish species is found to be abundant otherwise in the summer season the population declines as a result of declining food availability.

Tilapia food habits are similar to snakeskin fish and the frequency of spawning that is more frequent with the guarding of the tillers causes the tilapia to have greater survival rate and competition ability. As a herbivore fish with slightly more diverse food items compared to snakeskin fish, it is possible for tilapia to compete more with other types of fish in terms of space, food and recruitment so that this type of fish is almost abundant throughout the year.

Javabarb fish classified as planktivore fish who prefer to live on the surface with clear water conditions cause limitations in obtaining food in the form of plankton. Plankton abundance (fitolankton and zooplankton) is strongly influenced by water quality especially nutrients and sunlight (Parson at all.1998) During the rainy season the nutrient runoff of nitrate and phosphorus is much inland but low light intensity decreases with low plankton abundance. Therefore the abundance ofjavabarb fish food mainly occurs a few weeks after the peak of the rainy season where besides high nutrient sunlight is also available. The result is that the javabarb fish are not found abundantly in any time for a year as is the case with tilapia and it has something to do with the javabarb food habits.

As an omnivore fish that tends to be carnivore and tolerant to extreme environmental conditions causes fish to be obtained almost in all habitats and available throughout the year. However, the fecundity of this relatively small fish is only found during the rainy season unlike snakeskin fish and tilapia fish, it is said by Prianto, et al. (2014). The maturity level of fish gonad is affected 
by changes in water level. Based on eating habits and its tolerance to extreme habitats causes the fish to have a high competitive ability to survive in the lake ecosystem.

Snakehead fish as carnivore fish and predators of various types of fish and other nekton animals have a high dependence on the prey population in the availability of food. As a top predator in the lake ecosystem of the species of biomass fish is largely determined by the biomass of the fish that is prey. Conceptually predator fish population such as snakehead fish has smaller amount and biomass than their prey population. Another thing that causes the population of snakehead fish is not as much as herbivore fish and omnivore is a high economic value because it tastes good to be the target of fishing and must be one of the causes of low natural manipulation.

\subsection{ENVIRONMENTAL PARAMETERS}

The result of the measurement of several environmental parameters of Tempe lake at the time of the study were temperatures ranging from $30.7-31.4, \mathrm{pH}$ : 7.76 - 7.90, DO: 4.7 - 5.90, nutrient phosphate : 0.0359 0.0687 , Nitrate: $0.0015-0.0154$ and chlorophyl: 0.059 3.212. the measured environmental parameters data are all still within the limits that still strongly support the growth of existing organisms in the waters of Tempe lake.

\section{CONCLUTION AND SUGGESTION}

\subsection{Conclution}

4.1.1.Snakeskin fish and tilapia are classified as herbivore because from the analysis of the gastric are obtained phytoplankton, zooplankton, detritus, aquatic plants, insects and other benthic invertebrates and worms.

4.1.2.Goldfish and damselfish are classified as omnivore because based on gastric analysis are obtained water plants, phytoplankton, zooplankton, zoobenthos, detritus, insects, molluscs, worms, eggs or fish larvae and other invertebrate larvae.

4.1.3.Javabarb fish are classified as planktivorous fish because of the analysis of the gastric are obtained phytoplankton, zooplankton, aquatic plants, insects, and other invertebrate.

4.1.4.Snakehead fish is classified as carnivore because of the analysis of the gastric are obtained zoobenthos, fish, shrimp, other crustaceans, worms, frogs and other nekton

4.1.5.Based on the results of measurements of environmental parameters it was concluded that the carrying capacity of the environment as a habitat is still very supportive for the growth of fish in Tempe lake.

\subsection{SUGGESTION}

Need to research about trofik level and trofic level structure so that the waters condition ofTempe lake can be known how to transfer energy from one tropic to the next tropic.

\section{REFERENCES}

[1] Barus, TA., 2007. The Biodiversity of Lake Toba Ecosystem and Conservation Efforts. Article.

[2] Binder,T.R. 2011. FISH MIGRATION/The Biology Of Fish Migration. Cited By.23. Related Article

[3] Carmona J, at.all 1999. Distribution patterns of indigenous freshwater fishes in the Tagus River Basin, Spain. Environmental Biology of Fishes, 54

[4] Effendie, M.I. 1979. Fisheries Biology.. Yogyakarta: Nusantara Library Foundation.

[5] Effendi,H. 2007.Studi of Water quality for resource management and aquatic environment. Yogyakarta: PublisherKanisius. .

[6] Hatta, M., 2000. The structure and Dinamic of Trofic level in Fishing Ground Bagang Rambo Barru Regency. South Sulawesi. Disertation. Pasca Sarjana School. Bogor Agriculture Institute.

[7] Matthews CP, 1993. Produktivity and Energi flows at all trophic levels in. The river Thames, England: Mark 2, p.161 - 171. In V. Christensen and D.Pauly (eds). Trophic Models Of Aquatic Ecosystems. ICLARM Conf. Pro 26. Manila. International Center for living Aquatic Resources Management, International Council For the Exploration of The Sea, DANIDA.

[8] Samuel et all. 2010. Study Fishery Resource Stock in Tempe Lake. South Sulawesi. Technical Report. Marine and Fisheries Ministry. Marine and Fishery Research and Development agency. Research Center For Fisheries management and fish Resource Conservation. Fisheries Research Center Of Public Waters.

[9] ---- , 2010. Trophic Status and Estimated Potential of Fish Production In Waters Of Tempe Lake. South Sulawesi.

[10] Talalu, E., 2013. Tempe Lake. The Lake With The Most Fish In The World.

[11] Tamsil, A. 2000.,IkanBungo Biologi Reproduksidan Upay a Pelestariannya. Pustaka Refleksi. Makassar.2000.

[12] Unru, 2010.Unru, A.B. Pengelolaan Sumber Dayalkan di Danau Tempe. Kabupaten Wajo: Dinas Kelautandan Perikanan Kabupaten Wajo. 2010.

[13] Parson TR, Kessler TA. 1987. An ecosystem model for the assessment of plankton production in relation to the survival of young fish. J. Plankton Res

[14] Pauly D, Christensen V, Froese R, Polamares ML., 2000. Fishing down Aquatiq Food Webs.Am.Sci 88(1): 46 -51.

[15] Puudjirahaju, at. all., 2008.PenelusuranGenotipeikan Mas (CyprinuscarprioL) strain punten gy nogenetic.Jurnal Ilmu Ilmu Perikanan Indonesia. Vol 12 (1) : 13- 9. 
[16] War, M., K.Altaff and M.A. Haniffa., 2011. Growth and Survivalof Larval Snakehead Channa (Bloch, 1973). Fed Different Live Feed Organisms. Turkish Journal of Fisheris and Aquatiq Sciences.

[17] Whitten, A. J., M. Mustafa \& G. S. Henderson. Ekologi Sulawesi. Yogyakarta: Universitas Gajah Mada: 708-719 pp. 1987.

[18] Widy orini1. N., 2009. Feeding habit study of Pelagic Fish which Caught in the Area of seagrass with different densities in Pulau Panjang, Jepara. Journal of saintek Fisheries Vol. 5, No.2, 2010, 61 - 70

[19] Imorou, R., Adite, A., Sossoukpe, E., \& Abou, Y., 2019. Length-weight models and condition factors of fishes from Okpara Stream, Oueme River, Northern-Benin. International Journal Of Forest, Animal And Fisheries Research, Vol. 3, No.3, 65-80. doi: 10.22161/ijfaf.3.3.1

[20] Yamaji, C.S. 1979. Illustration of The Marine Plankton of Japan. Hoikiska Publ. Co. Ltd

[21] Zar, JH., 1984. Biostatistical Analysis. $2^{\text {nd }}$ Edition. New Jersey. Prentice-Hal International, Inc, Englewood Cliffs 